UDC 631.582:631.51

(C) 2016

M. Romashchenko, academician of NAAS, doctor of engineering science

O. Muzyka, Ph.D. in engineering science

Institute of Water Problems and Land Reclamation of NAAS

\author{
R. Vozhegova, M. Maliarchuk \\ doctors of Agricultural Science
}

Institute of Irrigated Agriculture of NAAS

\title{
PRODUCTIVITY OF CROP ROTATIONS ON IRRIGATED LANDS AT THEIR DIFFERENT SATURATION WITH GRAIN-GROWING AND TECHNICAL CULTURES
}

The purpose. To study possibility of irrigation systems to ensure scientifically justified regimens of irrigation of crops in crop rotations with different content of moistureloving crops of soya and corn. Methods. Field, laboratory, calculation. Results. Implementation for the last few years of structure of sown area and crop rotations with increased content of highly profitable moistureloving cultivated crops, such as soya and corn, which maximum water requirement is necessary for July and August, does not meet potential of operating irrigation systems to give in time necessary amount of water that results in disturbance of optimum regimens of their irrigation. Conclusions. At that stage of development of agribusiness industry existing state of irrigation systems it is impossible to apply high-intensive tilling systems of farming agriculture without holding complete redesign and remodeling of irrigation systems with simultaneous rising their water duty up to $0,7 \mathrm{l} / \mathrm{s} / \mathrm{hectare}$. On irrigated lands with water duty above $0,35 \mathrm{l} / \mathrm{s} /$ hectare it is expedient to apply 4-field crop rotations with parts of corn, soya and winter wheat 50, 25 and 25\% accordingly, or 25, 50 and $25 \%$ and 2 -field crop rotations with $50 \%$ content of soya and winter wheat. Rising of content of corn and soya in 2-3-field crop rotations up to $50,0-66,6 \%$ at existing irrigation systems results in disturbance of scientifically justified regimens of irrigation and impossibility of deriving design levels of productivity of these crops on all irrigation systems of Ukraine.

Key words: short-term crop rotations, irrigation, irrigated systems, water duty, soil fertility, profit.

Problem. An important task of agriculture is to achieve a stable, adequate to the bioclimatic potential, energy and economically justified productivity of cultivated crops; ecological safety of the environment, high quality and environmentally safe crop production $[2,3,5]$. Solving this problem depends on the effective use of land as the 
main means of production in agriculture. The most rational use of arable land, material and labor resources are ensured by the introduction of crop rotations. The development of theoretical foundations in accordance with the natural and climatic conditions of crop rotations and their practical application has a leading role in solving the main tasks of agriculture. Irregularities in crop rotations and technologies of growing crops leads to deterioration of the ecological condition of arable land, significant reduction in their productivity and effective soil fertility. [7, 9].

In the arid conditions in the south of Ukraine, where the limiting factor is moisture, to ensure sustainable yields of crops, it is necessary to cultivate them on irrigated lands. The lack of water for irrigation in this region calls for the development of scientific regulations and practical recommendations for the effective use of irrigated lands and water resources. One of the main factors in optimizing the use of irrigated lands and irrigation water is selection of crops with a high level of adaptation to the complex of natural and climatic factors and determination of their balance. [1, 4, 10].

The variety of soil, ameliorative, and economic factors necessitates a differentiated, integrated approach to the selection of crops and setting of crop rotations on irrigated lands. [6, 8].

Numerous experimental studies of domestic authors have shown that crops have different effects on the agrochemical state, biochemical activity, physical, waterphysical properties of the soil, the development of certain types of weeds, diseases and pests. As a result of such researches, the mechanisms of setting of field irrigated agrophytocenosis and crop rotation introduced within them, were grounded, that enables to stabilize the use of irrigated lands and increase their efficiency.

Experimentally studied and scientifically grounded the least cultivated crop rotations are inherent for the farms specializing in the production of grains and technical crops, that have been spread on irrigated lands of Ukraine during the last 10 years and for today from the total irrigation area in Ukraine (475 thousand hectares) 265.0 thousand hectares or $55.8 \%$ are used under these crops.

In these newly established large-scale enterprises, where there is no livestock sector, short crop rotations with soybeans, sunflower and maize for grain occupy a 
priority place. Spiked cereals and perennial grasses are practically not grown at that or occupy in the structure of crops to $10-15 \%$, and only individual farms sow winter wheat on $25 \%$ of the crop rotation area.

Such saturation of crop rotations on irrigated lands of Ukraine by clean-tilled crops (maize and soybeans), the total evaporation of which reaches $7000-8000 \mathrm{~m}^{3} / \mathrm{ha}$, with an average annual precipitation of $410 \mathrm{~mm}$ (4100 $\left.\mathrm{m}^{3} / \mathrm{ha}\right)$ in most cases leads to a violation of the recommended irrigation regimes that doesn't match the irrigation module of irrigation stations and systems in general. As a result, crop yields are decreasing and the quality of cultivated products are deteriorating. In addition, there are serious problems with the phytosanitary state of crops, the saline regime of irrigated soils is worsening and there is an increase in groundwater level, which leads to the ecological imbalance in the area of irrigation systems.

For farms of the irrigated zone at the stage of the agro-industrial complex development and in view of the current state of irrigation systems, power equipment and irrigation techniques, the transition to high-intensive farming systems requires their reconstruction with complete technical re-equipment.

The aim of the research is to provide a scientific substantiation of the parameters of optimal ratio and saturation of short-term crop rotations with some crops, which will ensure the preservation of soil fertility as well as profitability and stability of crop production.

The research was conducted during 2011-2014 at the central experimental base of the Institute of Irrigation Agriculture of NAAS in the zone of action of the Ingulets Irrigation System having a irrigation module of $0.35 \mathrm{l} / \mathrm{s} / \mathrm{ha}$. Experimental and extensive production implementation covers the basic farms in the operation zone of the Kakhovka Irrigation System and the North-Crimean Main Canel with the use of a complex of tillage machines and aggregates with different design of working bodies as well as "Frigate" and "Zimmatic" sprinkling machines. The experiment involves 6 field crop rotations with different parameters of their saturation with grain and technical crops (Table 1). 
1. Schemes of experimental crop rotations and the share of grain and technical crops in them

\begin{tabular}{|c|c|c|c|c|c|c|}
\hline \multirow{2}{*}{$\begin{array}{c}\text { Field, } \\
\text { № }\end{array}$} & \multicolumn{5}{|c|}{ 2-field } & \multicolumn{2}{c|}{ 3-field } & \multicolumn{2}{c|}{ 4-field } \\
\cline { 2 - 7 } & 1 & 2 & 3 & 4 & 5 & 6 \\
\hline \multirow{2}{*}{1} & $\underline{\text { soybeans }}$ & $\underline{\text { soybeans }}$ & $\underline{\text { soybeans }}$ & $\underline{\text { maize }}$ & $\underline{\text { soybeans }}$ & $\underline{\text { maize }}$ \\
\hline 2 & $\frac{50 \%}{50 \%}$ & $\underline{\text { maize }}$ & $\underline{\text { soybeans }}$ & $\underline{\text { maize }}$ & $\underline{\underline{\text { soybeans }}}$ & $\underline{\text { maize }}$ \\
\hline 3 & $50 \%$ & $33,3 \%$ & $33,3 \%$ & $25 \%$ & $25 \%$ \\
\hline 4 & & & $\underline{\text { maize }}$ & $\underline{\text { soybeans }}$ & $\underline{\text { maize }}$ & $\underline{\text { soybeans }}$ \\
\hline \multirow{2}{*}{5} & & & $33,4 \%$ & $33,4 \%$ & $25 \%$ & $25 \%$ \\
\hline
\end{tabular}

Note: in the numerator - crop; in the denominator - percentage of crop in crop rotation.

The technology of cultivating crops in the experiments was generally accepted for irrigated conditions. The soil of the experimental field is dark-chestnut mediumloam. The content of humus in the arable layer was $2.2 \%$. The field moisture-holding capacity of a 1-meter layer of soil is $21.3 \%$, and the withering point is $9.5 \%$.

Research results. For agricultural crops that are the part of experimental crop rotation, scientifically grounded irrigation regimes have been developed that are in line with their biological characteristics, and hence a different need for irrigation water during the growing season is formed. Due to the formation of a crop area structure in recent years, and, consequently, crop rotations with a high saturation of high-yield moisture-intensive crops such as soybeans and maize, the maximum water consumption of which is in July and August, the technical capacity of the functioning irrigation systems to provide water does not always meet the optimal regimes of their irrigation, especially in critical periods of development.

So, winter wheat and winter barley use more than $40 \%$ of irrigation water in May and partly in the first decade of June. For 42 days of irrigation season, winter wheat consumes $1800 \mathrm{~m}^{3}$ / ha, that is $42.8 \mathrm{~m}^{3}$ / ha per day, and winter barley uses the entire irrigation rate of $1400 \mathrm{~m}^{3}$ in May with an average daily consumption of 
irrigation water of $45.2 \mathrm{~m}^{3} /$ ha. The reduction of soil water storage in the soil layer of $0-50 \mathrm{~cm}$ up to the antecedent soil water $(70 \% \mathrm{FC})$ in the crops of maize and soybeans occurs at the beginning of the second decade of June. The irrigation period for these crops begins after completing the irrigation of winter wheat and wheat barley and lasts from 55 to 65 days for the mid-season hybrids of maize and up to 75-80 days for the mid-season breeds of soybeans, depending on the hydrothermal conditions of the growing season. For this period, the mid-season hybrid of maize COB- 329 MB used 60,0- 65,0 $\mathrm{m}^{3}$ / ha, and the breed of soybeans "Danaya" - 40,0$43,0 \mathrm{~m}^{3} / \mathrm{g}$ of irrigation water per day. It should be noted that maize consumes irrigation water during the irrigation period more evenly than soybeans. So, midseason hybrids of maize consume about 30\% of irrigation rate in June, in July - 45\% and in August - 25\%, while the mid-season soybeans consumes only $12 \%$ of irrigation water in June, in July - 33\% and in August - 55\% .

The weighted average irrigation rate for the experimental crop rotation reached $4300 \mathrm{~m}^{3}$ / ha in the fields with 50 and $66.6 \%$ of soybeans, as the water consumption peak of this crop is usually in the second month of summer. In August, in the crop rotations with $50 \%$ of soybeans it sharply decreases and makes up $3,000 \mathrm{~m}^{3}$ / ha, and in the fields with 50 and $66,6 \%$ of maize it reduces to 3500 and $3900 \mathrm{~m}^{3} /$ ha and remains rather high, that is, these two months are the most intensive as to water supply.

The analysis of the obtained values of the hydrodule using the scientific-grounded irrigation regimes for agricultural crops in short crop rotations in July made it possible to determine that it fluctuated within the range of 0.447-0.531 l / sec / ha. This suggests that this month is critical for 2- and 3-field crop rotation having 50 and $66.6 \%$ of soybeans and maize saturation. The design values of irrigation module of the functioning irrigation systems and their parts can not satisfy it.

For most crops, the research years (2011- 2014) were dry with a 95\% water deficit and therefore they are characterized by such large values of irrigation module, that is, they require a much higher amount of water in liters per second for 1 hectare of crop rotation area than it was provided by the design calculations.

All irrigated systems in Ukraine were designed for medium-dry years with a 
75\% water deficit, therefore, only in wet years Ukraine's main irrigation systems can provide a suitable level of moisture for crops in the crop rotations with increased (50-66\%) saturation of soybeans (Fig. 1).

Due to the increased aridity of climate for the last 20 years, the conditions of the natural moisturizing for plants have changed, and therefore the ratio of grains and technical crops in short crop rotations requires a further scientific study, particularly the reaction of these crops to the physical and mechanical state of soils and the formation of water supply regime and mineral nutrition that are formed under the influence of different ratios of agricultural crops, methods and depth of the main cultivation of soil and fertilizer doses.

In crop rotations on irrigated lands, the most typical and highly yielding crops are maize and soybeans, which for intensive growth and development require loose, enriched with nutrients and moisture arable and roots-free layer.

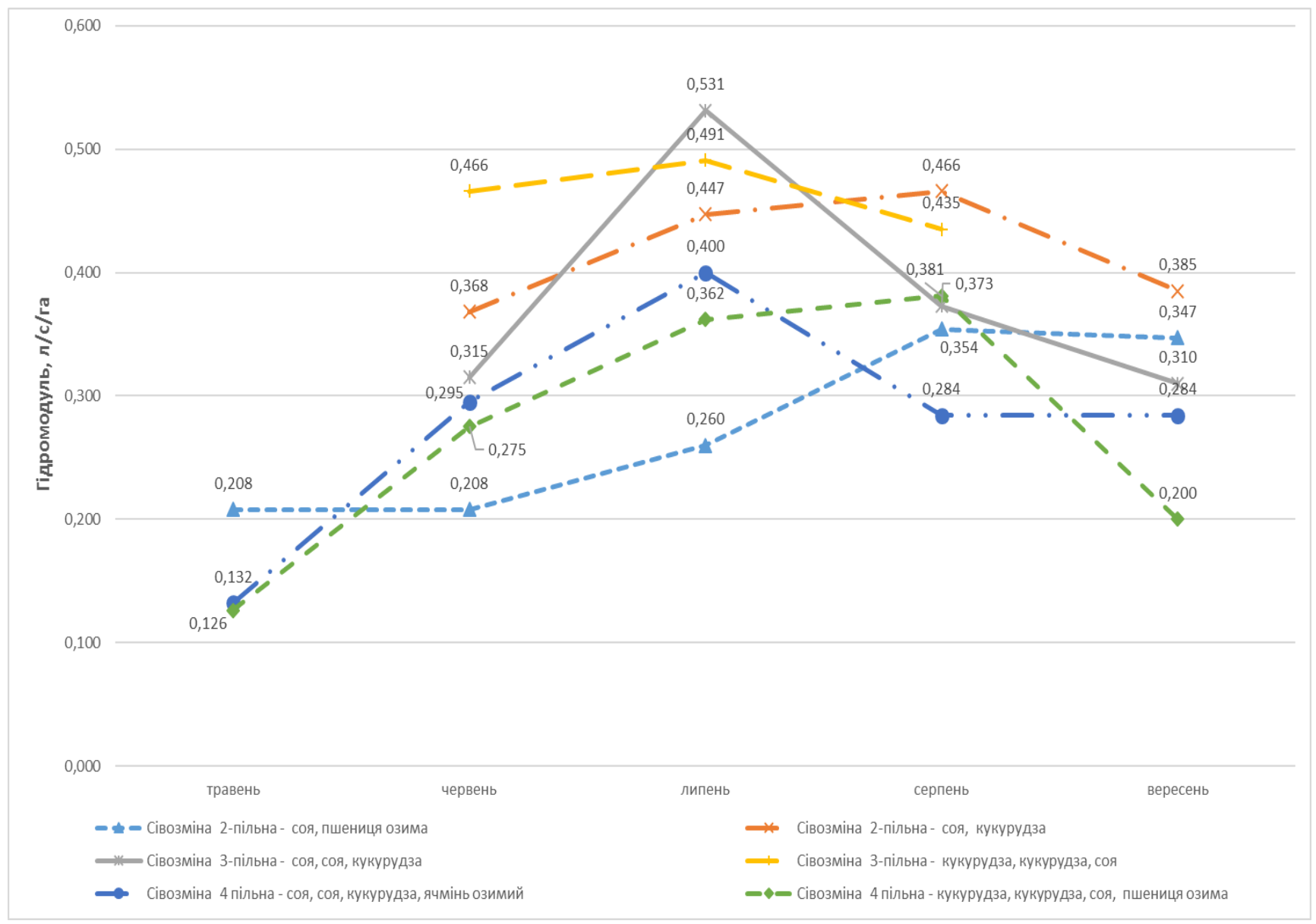

Fig. 1 Average ordinates of irrigation module for experimental crop rotations with different ratio of technical and grain crops using actual norms and terms of irrigation, $1 /$ sec /ha 
As a result of the research, it was found that the most suitable methods for the basic soil cultivation corresponding to those conditions are the ones with soil overturning, so that the density of the arable layer is reduced to $1.10-1.30 \mathrm{~g} / \mathrm{cm}^{3}$, afterharvesting residues and slow-moving phosphate fertilizers are turned into the soil to a depth of 20- 22 up to 28-30 cm, that is, in the zone of stable moisturizing and maximum spread of the root system, which contributes to increasing the nitrification capacity of the soil compared to shallow and surface boardless methods and systems of basic cultivation.

Thus, using an intended for different depth moldboard plowing at the beginning of maize and soybeans vegetation in a soil layer of $0-40 \mathrm{~cm}$, the nitrification capacity was $96.4-99.8 \mathrm{mg} / \mathrm{kg}$, and when using the boardless methods of cultivation, it decreased to $81.8-84.5 \mathrm{mg} / \mathrm{kg}$ of soil, or $15.2-15.4 \%$.

Considering the patterns of formation of the phosphoric-potassium regime of dark chestnut soils in crop rotations under irrigation with different saturations of maize and soybeans under the influence of different methods and systems of basic soil cultivation, fertilizers and irrigation regimes, it is necessary to take into account that the important source of soil replenishment by the elements of mineral nutrition is afterharvesting residues of soybeans, winter barley and grain maize that makes up 34, 4-5 and 11-12 t /ha having a coefficient of their use of $0.31,0.20$ and $0.30 \%$ respectively. Therefore, due to the large amount of organic matter obtained by means of mineral fertilizers and irrigation, the solubility of phosphates increases due to the significant acidification of the soil solution.

Favorable agrophysical soil state, water and nutritive regimes of soil provided optimal conditions for the growth and development of plants and for the formation of their productivity, which is the most important criterion for assessing crop rotations. In crop rotations with different saturations of grain and leguminous crops, the yield of maize ranged as 10,0-14,8 t/ha, soybeans - 3,15-3,52 t /ha, winter barley and winter wheat respectively 4,63-7,17 t /ha (Table 2). 


\section{Productivity and economic efficiency of the functioning of short-term}

crop rotations depending on the ratio of grain and technical crops in them

\begin{tabular}{|c|c|c|c|c|c|c|}
\hline \multirow[t]{3}{*}{ Indicator } & \multicolumn{6}{|c|}{ on average per 1 hectare of crop area } \\
\hline & \multicolumn{6}{|c|}{ Crop rotations } \\
\hline & $\begin{array}{c}\text { soybeans, } \\
\text { winter } \\
\text { wheat }\end{array}$ & $\begin{array}{c}\text { soybeans, } \\
\text { maize }\end{array}$ & $\begin{array}{l}\text { maize, } \\
\text { maize, } \\
\text { soybeans }\end{array}$ & $\begin{array}{c}\text { soybeans, } \\
\text { soybeans, } \\
\text { maize }\end{array}$ & $\begin{array}{c}\text { maize, maize, } \\
\text { soybeans, } \\
\text { winter wheat }\end{array}$ & $\begin{array}{c}\text { soybeans, } \\
\text { soybeans, } \\
\text { maize, } \\
\text { winter } \\
\text { barley }\end{array}$ \\
\hline $\begin{array}{l}\text { Output of feed } \\
\text { units, } \mathrm{t} \text { / ha }\end{array}$ & 6,22 & 10,19 & 10,27 & 6,21 & 11,9 & 7,45 \\
\hline $\begin{array}{l}\text { Cost of gross } \\
\text { output, hrn. }\end{array}$ & 13055 & 15180 & 19593 & 16533 & 15197 & 13394 \\
\hline Profit, hrn. / ha & 6351 & 7729 & 11535 & 8838 & 8195 & 6538 \\
\hline Profitability,\% & 97,9 & 103,3 & 140,0 & 112,0 & 117,7 & 95,0 \\
\hline $\begin{array}{c}\text { Payback for } \\
\text { irrigation water, } \\
\mathrm{kg} / \mathrm{m}^{3}\end{array}$ & 2,01 & 2,72 & 2,23 & 1,85 & 3,33 & 2,17 \\
\hline
\end{tabular}

When analyzing the data on the fodder value of all studied parts of crop rotations by the output of feed units per 1 hectare of crop rotation area, it has been determined that this indicator was the highest in the crop rotation № 5 (maize, maize, soybeans, winter wheat) and made it $11.9 \mathrm{t} / \mathrm{ha}$. This crop rotation is also characterized by the highest payback of water through the additional production, which was $3.33 \mathrm{~kg}$ per $1 \mathrm{~m}^{3}$ of water.

In the crop rotation with a $50 \%$ saturation of soybeans and maize, the output of feed units was lower by $1.71 \mathrm{t} /$ ha or by $16.7 \%$. Increasing the ration of soybeans in crop rotations has led to a decrease in productivity per a hectare of crop rotation area and, as a consequence, to the increase in self-cost of a feed unit.

Considering the indicators of economic efficiency of crop rotations under 
investigation it can be concluded about the undoubted advantage of the crop rotation № 3 (maize, maize, soybeans) where the value of gross output at the prices of 2014 per 1 hectare of crop rotation area were the highest and amounted to $19593 \mathrm{hrn}$. with a profitability level of $140 \%$. However, due to the high costs of irrigation water during the critical period in this crop rotation compared to the crop rotation № 5 , the payback of irrigation water is reduced by the value of additional production by $33.0 \%$ and makes it as $2.23 \mathrm{~kg}$ per $1 \mathrm{~m}^{3}$ of water.

The conducted studies indicate that the saturation of crop rotation № 4 with soybeans in the range of $66.6 \%$ makes it possible to reduce the dose of mineral fertilizers, due to the inoculation of soybean seeds with bacterial preparations, by 44$59 \%$. At the same time, increasing the ratio of soybeans in crop rotation allows reducing material costs for the purchase of mineral fertilizers as well as decreasing the anthropogenic load on the soil and environment.

By calculating the actual value of irrigation module when using scientifically grounded irrigation regimes for crops in the studied short-term rotations in July, it was found that its values were within the range of $0.447-0.531 \mathrm{l} / \mathrm{s} / \mathrm{ha}$. This indicates that this month is critical for two- and three-field crop rotations with 50 and $66 \%$ of soybeans and maize saturation. The design values of the irrigation module of the functioning irrigation systems and their parts are unable to provide it.

\section{Conclusions}

For the farms of the irrigated zone at the current stage of development of the agro-industrial complex in view of the existing state of irrigation systems, power equipment and sprinkling equipment, it is impossible to use high- intensity tillage systems of agriculture without their complete rehabilitation and modernization with a simultaneous increase of the irrigation module of such systems up to $0.7 \mathrm{l} / \mathrm{s} / \mathrm{ha}$.

On the existing irrigation systems with an irrigation module above $0.35 \mathrm{l} / \mathrm{s} / \mathrm{ha}$, that is, at Kakhovska, Inguletska, Frunzenska, Danube-Dnistrovska, SolonyanoTomakovska, North-Rogachinska and on the second line of the Krasnoznamenska irrigation system, it is advisable to use 4-field crop rotations with a ratio of maize, soybeans and winter wheat respectively: 50, 25 and 25\%; or 25, 50 and 25\%, as well 
as 2-field crop rotations with $50 \%$ saturation of soybeans and winter wheat.

Increasing the ratio of maize and soybeans in 2-3-field crop rotations to 50.0$66.6 \%$ leads to a disturbance in scientifically grounded irrigation regimes and the inability to obtain the project yields of these crops on all irrigation systems in Ukraine, except the first line of the Krasnoznamenska irrigation system with the irrigation module of $0.69 \mathrm{l} / \mathrm{s} / \mathrm{ha}$.

\section{Bibliography}

1. Boyko P.I. Factor of crop rotation in weed control/[P.I. Boyko, N.P. Kovalenko, G.M. Panasyuk etc.]//Materials of the $4^{\text {th }}$ Conference of herbologists "Problems of weeds and ways to reduce the weed infestation of arable land." - K .: Koloobig, 2004. - P. 78-83.

2. Bulygin S.Y. Formation of ecologically balanced landscapes / S.Y. Bulygin, I.A. Nearing - 1999. - 272 p.

3.Kaminsky V.F. The role of crop rotation in modern agriculture/V.F. Kaminsky, P.I. Boyko//Bulletin of Agrarian Science - 2013. - № 6. - P. 5-9.

4. Vozhegova R.A. Systems of agriculture on irrigated lands of Ukraine/[R.A.Vozhegova, A.S. Zarishnyak, M.I. Romashchenko, M.P. Malyarchuk, etc.] - K .: Agrarian Science, 2014.-360 p.

5. Kisil V.I. Model of biological agriculture of the Institute of Soil Science and Agrochemistry of UAAS/V.I. Kisil//Soil protection biological system of agriculture of Ukraine. - K., 2000. - P. 185-195.

6. Kovalenko A.M. Crop rotation is an important component of the effective use of irrigated land/A.M. Kovalenko//Cross sectoral thematic scientific collection: Agriculture. - 2015. - 1. - pp. 88-92.

6. Lebid Y.M. Scientific foundation of agro-industrial production in the Steppe zone of Ukraine/Y.M. Lebid [ed. M.V. Zubets]. - K.: Agrarian Science, 2010. - 986 p. 7. Lymar A.O. Short crop rotations on irrigated lands/A.O. Lymar, V.A. Lymar. - Kherson: Aylant, 2009. - 248 p.

8.Saiko V.F. Crop rotations in the agriculture of Ukraine/V.F. Saiko, P.I. Boyko - K.: Agrarian Science, 2002. - 146 p. 
9. Frasier G. Runoff farming - Irrigation technology of the future. Future irrigation strategies/G. Frasier//Visions of the Future. Proceedings of the $5^{\text {th }}$ National Irrigation Symposium, 2003. Phoenix. - R. 124-137. 